\title{
Front Matter: Volume 7779
}

, "Front Matter: Volume 7779," Proc. SPIE 7779, Organic Semiconductors in Sensors and Bioelectronics III, 777901 (21 September 2010); doi:

10.1117/12.876879

SPIE Event: SPIE Photonic Devices + Applications, 2010, San Diego, California, SPIE. United States 


\title{
PROCEEDINGS OF SPIE
}

\section{Organic Semiconductors in Sensors and Bioelectronics III}

\author{
Ruth Shinar \\ loannis Kymissis \\ Editors
}

4-5 August 2010

San Diego, California, United States

Sponsored and Published by

SPIE

Volume 7779

Proceedings of SPIE, 0277-786X, v. 7779 
The papers included in this volume were part of the technical conference cited on the cover and title page. Papers were selected and subject to review by the editors and conference program committee. Some conference presentations may not be available for publication. The papers published in these proceedings reflect the work and thoughts of the authors and are published herein as submitted. The publisher is not responsible for the validity of the information or for any outcomes resulting from reliance thereon.

Please use the following format to cite material from this book:

Author(s), "Title of Paper," in Organic Semiconductors in Sensors and Bioelectronics III, edited by Ruth Shinar, loannis Kymissis, Proceedings of SPIE Vol. 7779 (SPIE, Bellingham, WA, 2010) Article CID Number.

ISSN 0277-786X

ISBN 9780819482754

Published by

SPIE

P.O. Box 10, Bellingham, Washington 98227-0010 USA

Telephone +1 3606763290 (Pacific Time) · Fax +1 3606471445

SPIE.org

Copyright (C) 2010, Society of Photo-Optical Instrumentation Engineers

Copying of material in this book for internal or personal use, or for the internal or personal use of specific clients, beyond the fair use provisions granted by the U.S. Copyright Law is authorized by SPIE subject to payment of copying fees. The Transactional Reporting Service base fee for this volume is $\$ 18.00$ per article (or portion thereof), which should be paid directly to the Copyright Clearance Center (CCC), 222 Rosewood Drive, Danvers, MA 01923. Payment may also be made electronically through CCC Online at copyright.com. Other copying for republication, resale, advertising or promotion, or any form of systematic or multiple reproduction of any material in this book is prohibited except with permission in writing from the publisher. The CCC fee code is 0277-786X/10/\$18.00.

Printed in the United States of America.

Publication of record for individual papers is online in the SPIE Digital Library.

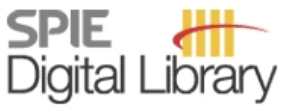

SPIEDigitalLibrary.org

Paper Numbering: Proceedings of SPIE follow an e-First publication model, with papers published first online and then in print and on CD-ROM. Papers are published as they are submitted and meet publication criteria. A unique, consistent, permanent citation identifier (CID) number is assigned to each article at the time of the first publication. Utilization of CIDs allows articles to be fully citable as soon they are published online, and connects the same identifier to all online, print, and electronic versions of the publication. SPIE uses a six-digit CID article numbering system in which:

- The first four digits correspond to the SPIE volume number.

- The last two digits indicate publication order within the volume using a Base 36 numbering system employing both numerals and letters. These two-number sets start with 00, 01, 02, 03, 04, $05,06,07,08,09,0 A, 0 B \ldots 0 Z$, followed by 10-1Z, 20-2Z, etc.

The CID number appears on each page of the manuscript. The complete citation is used on the first page, and an abbreviated version on subsequent pages. Numbers in the index correspond to the last two digits of the six-digit CID number. 


\title{
Contents
}

\author{
$\checkmark \quad$ Conference Committee
}

\section{SESSION 1 ORGANIC SEMICONDUCTORS IN SENSORS AND BIOELECTRONICS I}

777904 Optochemical sensor based on screenprinted fluorescent sensorspots surrounded by organic photodiodes for multianalyte detection [7779-03]

E. Kraker, B. Lamprecht, A. Haase, G. Jakopic, JOANNEUM RESEARCH

Forschungsgesellschaft mbH (Austria); T. Abel, Technische Univ. Graz (Austria); C. Konrad,

S. Köstler, M. Tscherner, B. Stadlober, JOANNEUM RESEARCH Forschungsgesellschaft mbH

(Austria); T. Mayr, Technische Univ. Graz (Austria)

\section{SESSION 2 ORGANIC SEMICONDUCTORS IN SENSORS AND BIOELECTRONICS II}

777908 Large-area stretchable sensors with integrating organic CMOS ICs with Si-CMOS LSIs (Invited Paper) [7779-07]

T. Sekitani, K. Ishida, The Univ. of Tokyo (Japan); U. Zschieschang, H. Klauk, Max-Planck-Institut für Festkörperforschung (Germany); M. Takamiya, T. Sakurai, T. Someya, The Univ. of Tokyo (Japan)

7779 OA Ink-jet printed colorimetric gas sensors on plastic foil (Invited Paper) [7779-09] J. Courbat, D. Briand, N. F. de Rooij, Ecole Polytechnique Fédérale de Lausanne (Switzerland)

\section{SESSION 3 ORGANIC SEMICONDUCTORS IN SENSORS AND BIOELECTRONICS III}

7779 OF An organic semiconductor device for detecting ionizing radiation on a cellular level [7779-14]

M. Bardash, QEL System Services, Inc. (United States)

\section{SESSION 4 ORGANIC SEMICONDUCTORS IN SENSORS AND BIOELECTRONICS IV}

7779 OG Organic field-effect transistors applicable for gas and ion detection (Invited Paper) [7779-15]

A. Klug, K. Schmoltner, NanoTecCenter Weiz Forschungsgesellschaft mbH (Austria);

E. J. W. List, NanoTecCenter Weiz Forschungsgesellschaft mbH (Austria) and Technische Univ. Graz (Austria)

$7779 \mathrm{OH}$ Fabrication and characterization of carbon nanotube field-effect transistor biosensors (Invited Paper) [7779-16]

M. R. Leyden, C. Schuman, T. Sharf, J. Kevek, V. T. Remcho, E. D. Minot, Oregon State Univ. (United States) 


\section{SESSION 5 ORGANIC SEMICONDUCTORS IN SENSORS AND BIOELECTRONICS V}

7779 OK Luminescent conjugated oligothiophenes: optical dyes for revealing pathological hallmarks of protein misfolding diseases (Invited Paper) [7779-19]

P. Hammarström, Linköping Univ. (Sweden); M. Lindgren, Linköping Univ. (Sweden) and Norwegian Univ. of Science and Technology (Norway); K. P. R. Nilsson, Linköping Univ. (Sweden)

\section{SESSION 6 ORGANIC SEMICONDUCTORS IN SENSORS AND BIOELECTRONICS VI}

777900 Performance and parameter variation of flexible organic thin film transistors in multicomponent organic sensors (Invited Paper) [7779-23]

B. Stadlober, A. Fian, A. Haase, E. Kraker, M. Zirkl, G. Scheipl, G. Jakopic, JOANNEUM RESEARCH Forschungsgesellschaft mbH (Austria)

7779 OP Advances toward commercialization of a new generation of low cost (O)LED-based dissolved oxygen and bioanalyte monitors (Invited Paper) [7779-24]

A. Smith, Integrated Sensor Technologies, Inc. (United States); Y. Cai, Ames Lab., Dept. of Energy (United States) and lowa State Univ. (United States); S. Vengasandra, Integrated Sensor Technologies, Inc. (United States); R. Shinar, Integrated Sensor Technologies, Inc. (United States) and lowa State Univ. (United States); J. Shinar, Integrated Sensor Technologies, Inc. (United States), Ames Lab., Dept. of Energy (United States), and lowa State Univ. (United States)

\section{POSTER SESSION}

$77790 Q \quad$ A green-absorbing dendrimer-based photodetector for image sensing applications [7779-25]

R. D. Jansen-van Vuuren, A. K. Pandey, The Univ. of Queensland (Australia); S. Collins, Univ. of Oxford (United Kingdom); P. L. Burn, The Univ. of Queensland (Australia) 


\title{
Conference Committee
}

\author{
Symposium Chair
}

Zakya H. Kafafi, National Science Foundation (United States)

Conference Chair

Ruth Shinar, lowa State University (United States)

Conference Cochair

loannis Kymissis, Columbia University (United States)

Program Committee

Magnus Berggren, Linköpings Universitet (Sweden)

Graciela B. Blanchet, Nano-Terra, Inc. (United States)

Sumit Chaudhary, lowa State University (United States)

Emil J. W. List, Technische Universität Graz (Austria)

Róisín Owens, École Nationale Supérieure des Mines de Saint-Étienne (France)

Franky So, University of Florida (United States)

Luisa Torsi, Università degli Studi di Bari (Italy)

Session Chairs

1 Organic Semiconductors in Sensors and Bioelectronics I

Emil J. W. List, Technische Universität Graz (Austria)

2 Organic Semiconductors in Sensors and Bioelectronics II

John C. de Mello, Imperial College London (United Kingdom)

3 Organic Semiconductors in Sensors and Bioelectronics III

Ethan D. Minot, Oregon State University (United States)

4 Organic Semiconductors in Sensors and Bioelectronics IV

Barbara Stadlober, JOANNEUM RESEARCH Forschungsgesellschaft $\mathrm{mbH}$ (Austria)

5 Organic Semiconductors in Sensors and Bioelectronics $V$ Sumit Chaudhary, lowa State University (United States)

6 Organic Semiconductors in Sensors and Bioelectronics VI Paul L. Burn, The University of Queensland (Australia) 
Downloaded From: https://www.spiedigitallibrary.org/conference-proceedings-of-spie on 26 Apr 2023

Terms of Use: https://www.spiedigitallibrary.org/terms-of-use 